\title{
Restorative Justice Terhadap Pelaku Tindak Pidana Ringan yang Telah diberi Sanksi Adat
}

\author{
Yogi Hardiman ${ }^{1}$, Siti Kotijah ${ }^{2}$, La Sina ${ }^{3}$ \\ ${ }^{1}$ Magister's Program faculty of Mulawarman University. \\ ${ }^{2}$ Lecture of Faculty of Law, Mulawarman University \\ Email : sskotijah8@gmail.com \\ ${ }^{3}$ Lecture of Faculty of Law, Mulawarman University \\ Email : lasina.fhunmul@gmail.com
}

\begin{abstract}
Proses penyelesaian pelanggaran hukum adat, dengan diberikan sanksi adat oleh lembaga adat, dibenarkan sebagai bentuk perwujudan keberadaan dan pengakuan hukum adat yang masih ada dan tumbuh dalam masyarakat di Indonesi dan diakui proses itu oleh kepolisia sebagai penyelesaian sengketa diluar pengadilan. Penelitian ini,yuridis empiris, dengan pendekatan studi kasus Suku Dayak Wehea Desa Nehes Liah Bing oleh kepolisian Kutai Timur. Penyelesaian adat atas tindak pidana ringan yang telah diberikan sanksi adat oleh Suku dayak wehea berdasarkan hukum adat itu,menjadi dasar pihak kepolisian memberlakukan penerapan restoratif justice terhadap pelaku tindak pidana ringan yang telah diberikan sanksi adat di Satuan Reserse Kriminal Kepolisian Resor Kutai Timur. Penerapan restoratif justice terhadap pelaku tindak pidana ringan yang telah diberikan sanksi adat di Satuan Reserse Kriminal Kepolisian Resor Kutai Timur merupakan role model dalam proses penyelesaian sengketa diluar pengadilan. Upaya ini menjadi lebih mudah, murah, dan tidak berbelit-belit, dan memberi kepastian hukum kepada korban dan pelaku tindak pidana pelanggaran ringan.
\end{abstract}

Keywords: restoratif justice, sanksi adat, Polisi.

Citation: hardiman, Yogi, dkk. Restorative justice Terhadap Pelaku Tindak Pidana yang Telah diberi Sankdi Adat, Mulawarman Law Review 4, no. 1 (2019)

\section{PENDAHULUAN}

Pembentukan hukum di Indonesia berupa hukum nasional, hukum islam, dan hukum adat. Hukum adat menjadi hukum yang tidak terpisahkan dengan hukum yang ada, tumbuh dan berkembang di masyarakat hukum adat. Setiap pelaku kejahatan baik bersifat berat atau ringan di masyarakat hukum adat, selalu diproses diberikan sanksi 
pada pelaku sesuai dengan kejahatan dan hukum adat yang berlaku. Di sisi lain kepolisian sebagai penegak hukum, menjalankan fungsi keamanan dan ketertiban dalam masyarakat, termasuk di dalamnya masyarakat hukum adat. Pelanggaran dan kejahatan diatur di Kitab Undang-Undang Hukum Acara Pidana (KUHP) yang membahas mengenai sanksi yang dapat dikenakan kepada seseorang apabila melakukan perbuatan melanggar hukum. Namun di masyarakat hukum adat, sanksi adat terhadap pelanggaran dan kejahatan tetap diberlakukan. Sehubungan dengan itu, di wilayah hukum Kepolisian Resor (Polres) Kutai Timur, ada pola hubungan hukum penyelesaian hukum adat dan hukum negara. Hal ini mengingat masyarakat masih memegang hukum adat yang telah berlangsung secara turun temurun. Pelaku tindak pidana yang melakukan pelanggaran ringan dikenakan sanksi sesuai dengan adat yang berlaku melalui lembaga adat yang telah terbentuk di daerah yang bersangkutan, sebelum diserahkan kepada pihak berwajib (Polri). Sanksi adat yang diberikan oleh lembaga adat pada umumnya bersifat konstruktif bagi pelaku tindak pidana diantaranya adalah sanksi denda adat, pengucilan, diarak keliling kampung, melakukan cuci kampung dengan memotong hewan dan diberikan kepada warga masyarakat sekitar, serta pengusiran dari daerah tertentu.

Sanksi adat bagi pelaku dalam penerapan hukum adat masih digunakan masyarakat Kecamatan Muara Wahao Kabupaten Kutim. Aturan-aturan adat ini memiliki peranan di dalam menegakkan hukum adat, untuk dijadikan pedoman dan acuan bertingkah laku bagi warga masyarakatnya serta diharapkan tidak terjadinya penyimpangan sosial. Salah satu contohnya Desa Nehas Liah Bing memiliki lembaga adat yang memiliki fungsi untuk menyelesaikan permasalahan-permasalahan di dalam masyarakat desa. Perkara penganiayaan dan perkelahian yang sudah dilaporkan kepada pihak Kepolisian Sektor Muara Wahao, yaitu perkara berdasarkan LP/59/III/2015/Kaltim/Res Kutai Timur/Sektor Muara Wahao tanggal 7 maret 2015 yang terjadi pada tanggal 7 maret tahun 2015 dengan Tempat Kejadian Perkara (TKP) di kediaman korban yaitu di Desa Nehas Liah Bing, Kecamatan Muara Wahao dengan pelapor Yohana, tempat tinggal di Desa Nehas Liah Bing, Kecamatan Muara Wahao, kelahiran 25 mei 1976, jenis kelamin 
perempuan, Suku Dayak Wehea, pekerjaan ibu rumah tangga, agama katholik. Sedangkan terlapor yaitu Florianus Avun, tempat tinggal di Desa Nehas Liah Bing, Kecamatan Muara Wahao, umur 39 Tahun, jenis kelamin laki-laki, pekerjaan swasta, agama katholik.

Perkara ini sudah dilaporkan dan ditindak lanjuti secara resmi oleh pihak Kepolisian Sektor Muara Wahao. Pada perkara di atas, kepolisian melakukan tindakan restorative justice, ini sesuai dengan Pasal 18 Undang-Undang Kepolisian No 2 Tahun 2002 tentang Kepolisian Negara Republik Indonesia yang mengatur mengenai diskresi kepolisian dan surat Keputusan Kapolri Nomor : B/3022/XII/2009/SDEOPS tentang penanganan kasus melalui Alternatif Despute Resolution (ADR) tanggal 14 Desember Tahun 2009. Pada dasarnya kepolisian dalam penanganan perkara pelanggaran tindak pidana ringan, penerapan Alternatif Despute Resolution (ADR) ini didahulukan, khususnya terhadap perkara yang telah diselesaikan dan diberikan sanksi hukum adat oleh lembaga adat dapat dijadikan pertimbangan oleh pihak kepolisian untuk menghentikan perkara tersebut sesuai dengan konsep restorative justice, sehingga dapat memberikan rasa keadilan, kepastian dan kemanfaatan hukum. Penelitian ini mengkaji penerapan restoratif justice terhadap pelaku tindak pidana ringan yang telah diberikan sanksi adat di Satuan Reserse Kriminal Kepolisian Resor Kutai Timur

\section{METODE}

Penelitian menggunakan metode penelitian yuridis empiris, dengan menggunakan pendekatan kasus dan penelitian lapangan di Desa Nehes Liah Bing. Data yang diperoleh dianalisis dan diuraikan secara deskriptif untuk menarik kesimpulan.

\section{PEMBAHASAN}

Proses penerapan sanksi adat berdasarkan hukum adat Suku Dayak Wehea Desa Nehes Liah Bing bagi pelaku pelanggaran adat atau tindak pidana ringan.

Penerapan restoratif justice diberlakukan pada Satuan Reserse Kriminal Kepolisian Resor Kutai Timur, terkait perkara pelaku tindak pidana ringan berasal dari Suku Dayak Wehea Desa Nehes Liah Bing. Suku Dayak Wehea adalah sub suku Dayak Kalimantan 
yang merupakan masyarakat asli dan pertama kali mendiami wilayah-wilayah di Kecamatan Muara Wehea (biasa disebut wahao oleh orang luar), serta tersebar pada 2 (dua) sungai besar yaitu Sungai tlan (biasa disebut sungai telen).Kemudian sekitar tahun 1970 banyak penduduk yang mendiami desa-desa tersebut, diantaranya adalah dari Suku Dayak Kenyah, Suku Dayak Modang, Suku Dayak Punan, Suku Dayak Bahao, Suku Dayak Tunjung, Suku Dayak Benoa dan Suku Dayak Kayan. Seiring dengan beroperasinya perusahaan-perusahaan asing tersebut maka bermunculan desa-desa baru, sehingga saat ini pada Kecamatan Muara Wahao terdapat 10 (sepuluh) desa diantaranya adalah : Desa Benhes, Desa Dabeq, Desa Diaq lay, Desa Jak Luay, Desa Karya Bakti, Desa Long Wehea, Desa Muara Wahao, Desa Nehas Liah Bing, Desa Wahao Baru dan Desa Wanasari.

Lembaga Adat Dayak Wehea Desa Nehes Liah Bing merupakan wadah organisasi adat guna memelihara adat istiadat yang ada, melestarikan tradisi budaya masyarakat tersebut. Fungsi kepala adat itu dibedakan dalam 2 (dua) bagian, yang pertama sebagai satuan institusional yang disebut sebagai kapakat isen mulang adat yang merupakan lembaga peradilan adat berjenjang. Dalam pengertian kedua yang bersifat parsial yaitu ketua adat diartikan sebagai hakim adat yang mengadili perkara adat pada tingkat desa. Pada Desa Nehes Liah Bing, kepala adat mempunyai tugas rangkap yaitu disatu pihak sebagai kepala adat, di pihak lain bertugas sebagai pelaksana pemerintahan desa yaitu sebagai kepala desa. Pada lembaga adat ini terdiri dari ketua dewan adat, sekretaris adat, kepala desa atau kepala adat, wakil kepala adat, kepala sub bidang pernikahan "plulukng"1, kepala sub bidang perkara, kepala sub bidang adat dan budaya, Badan Permusyawaratan Desa (BPD), tokoh masyarakat (penasihat penyelesaian). ${ }^{2}$ Sehingga keberadaan lembaga adat atau kapakat isen mulang wehea ini yang terdiri dari tetua dan tokoh adat lainnya dapat berfungsi menyelesaikan permasalahan yang ada di dalam masyarakat, lebih jelas pada bagan 1.

\footnotetext{
${ }^{1}$ Wawancara dengan Ladjie Taq mengenai definisi "plulukng" adalah kepala sub bidang perkara pada lembaga peradilan adat Desa Nehes Liah Bing.

${ }^{2}$ Wawancara dengan Ladjie Taq, Ketua Adat merangkap Kepala Desa Nehas Liah Bing, tanggal 17 Desember 2015.
} 
Bagan 1 :

\section{Struktur Organisasi Lembaga Adat Desa Nehas Liah Bing}

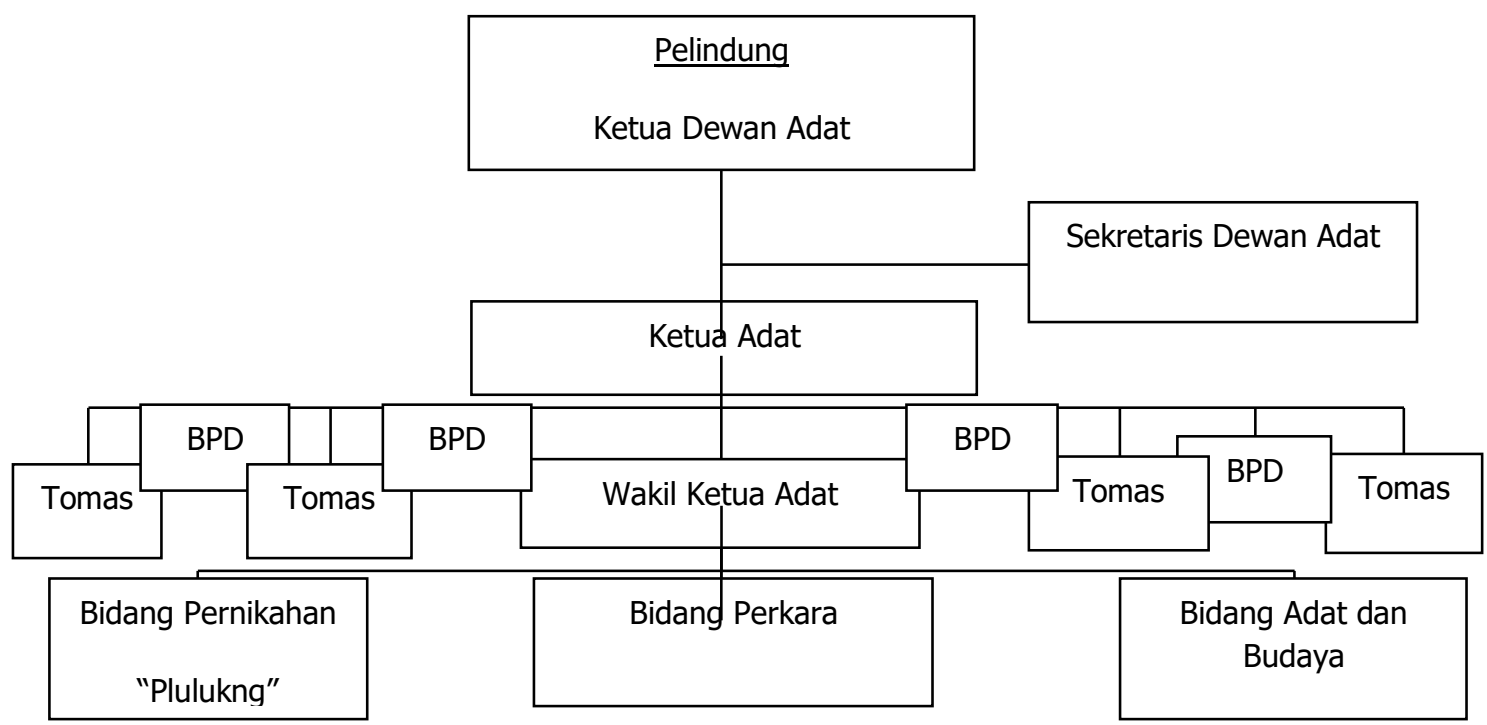

Prosedur penanganan permasalahan lembaga adat di Desa Nehas Liah Bing, tidak memiliki aturan secara tertulis khususnya pada lembaga adat di dalam menangani permasalahan-permasalahan yang terjadi di dalam masyarakat, sehingga penanganan permasalahan-permasalahan warga ini hanya berlaku secara adat kebiasaan yang dilakukan secara turun temurun oleh beberapa generasi suku.

Berkaitan dengan permasalahan penganiayaan ringan terjadi pada tanggal tujuh Maret tahun 2015 dengan tempat kejadian perkara (TKP) di kediaman korban yaitu di Desa Nehas Liah Bing, Kecamatan Muara Wahao dengan korban Yohana, suku dayak wehea, pekerjaan ibu rumah tangga, agama Katholik dan pihak pelanggar adat yaitu Florianus Avun. Setelah permasalahan tersebut dilaporkan kepada ketua atau hakim adat, maka akan diadakan penyelesaian adat dengan mengadakan kapakat isen mulang wehea atau peradilan adat yang terdiri dari ketua dewan adat, sekretaris adat, kepala desa atau kepala adat, wakil kepala adat, kepala sub bidang pernikahan "plulukng", kepala sub bidang perkara, kepala sub bidang adat dan budaya, Badan Permusyawaratan Desa (BPD), tokoh masyarakat (penasihat penyelesaian). 
Sebelum peradilan adat dimulai maka terlebih dahulu akan diadakan "tepung tawar," yaitu berupa piring atau daun pisang yang berisikan telur ayam kampung, kunir, tepung atau beras dengan tujuan untuk membersihkan dan menghindari roh atau arwah jahat yang akan mengganggu pelaksanaan peradilan tersebut. Prosesi tepung tawar merupakan prosesi yang wajib dilaksanakan sebelum dimulainya sidang pada peradilan lembaga adat guna membersihkan jiwa raga dari pelaku pelanggar adat maupun dari pihak korban sehingga terhindar dari rasa dendam. Setelah sidang peradilan adat selesai dilaksanakan maka akan ada ritual selanjutnya yaitu berupa "meninyau pagar berempayang kuta" yaitu ritual yang berupa piring putih diberikan kepada pelaku pelanggar adat dengan tujuan agar pelaku tidak mengulangi perbuatan tersebut dan apabila pelaku mengulangi perbuatan tersebut maka lembaga adat tidak akan segan-segan untuk memberikan sanksi yang lebih berat. ${ }^{4}$ Menurut Ketua Adat Desa Nehas Liah Bing Ladjie Taq mengatakan bahwa sanksi adat yang diberikan oleh lembaga adat Desa Nehes Liah bing terhadap pelaku palanggar adat, diantaranya adalah ${ }^{5}$ Penggantian kerugian immaterial; Pembayaran uang dan denda adat; Berselamatan atau ritual upacara dalam rangka membersihkan masyarakat dari kotoran gaib dengan melakukan pemotongan hewan yang diberikan kepada seluruh warga desa; Penuntutan permohonan maaf; Hukuman fisik sampai pada hukuman mati; Pengasingan dan pengucilan dari masyarakat desa; dan diarak keliling kampung. Terkait dengan sanksi adat pada perkara ini, maka keputusan lembaga adat atau kapakat isen mulang wehea memberikan sanksi kepada pelaku pelanggar adat yaitu Florianus Avun dengan perkara penganiayaan ringan terhadap Yohana yaitu sebagai berikut: ${ }^{6}$

\footnotetext{
3 Wawancara dengan Ladjie Taq mengenai definisi "tepung tawar" adalah ritual untuk membersihkan dan menghindari roh atau arwah jahat yang akan mengganggu pelaksanaan peradilan adat di Desa Nehes Liah Bing.

${ }^{4}$ Ibid.

${ }^{5}$ Wawancara dengan Ladjie Taq, Ketua Adat merangkap Kepala Desa Nehas Liah Bing, tanggal 17 Desember 2015.

${ }^{6}$ Wawancara dengan Ladjie Taq, Ketua Adat merangkap Kepala Desa Nehes Liah Bing, Kecamatan Muara Wahao, Kabupaten Kutai Timur, Tanggal 17 Desember 2015.
} 
(1). Florianus Avun tempat tinggal di Desa Nehas Liah Bing, Kecamatan Muara Wahao, umur 39 Tahun, jenis kelamin laki-laki, pekerjaan swasta, agama katholik, disebut sebagai pihak pertama; dan

(2). Yohana, tempat tinggal di Desa Nehas Liah Bing, Kecamatan Muara Wahao, kelahiran 25 mei 1976, jenis kelamin perempuan, Suku Dayak Wehea, pekerjaan ibu rumah tangga, agama katholik, disebut sebagai pihak kedua; dan

(3). Pihak pertama meminta maaf kepada pihak kedua; dan

(4). Pihak kedua menerima permintaan maaf dari pihak pertama; dan

(5). Pihak pertama sanggup membayarkan biaya pengobatan dan antang kepada pihak kedua, sebesar 4 antang yaitu Rp 1.600.000,- (satu juta enam ratus ribu rupiah).

Pada kasus diatas setelah dilakukan musyawarah bersama oleh lembaga adat, pada akhirnya diputuskan pembayaran denda adat berupa permintaan maaf dari pihak pelaku terhadap pihak korban dan 4 (empat) buah antang yaitu dengan nilai uang $\mathrm{Rp}$ 1.600.000,- (satu juta enam ratus ribu rupiah) yang diberikan kepada korban sebagai bentuk ganti kerugian. Hal ini merupakan suatu bentuk pemidanaan karena dengan adanya denda adat yang telah diputuskan oleh lembaga adat. Pada hakekatnya keberadaan mengenai hukum adat Desa Nehes Liah Bing beserta hak-hak tradisionalnya telah diakui oleh Indonesia. ${ }^{7}$

\footnotetext{
${ }^{7}$ Pasal 18 huruf b Amandemen Undang-Undang Dasar 1945 Bab VI tentang Pemerintahan Daerah (a) Negara mengakui dan menghormati satuan-satuan pemerintahan daerah yang bersifat khusus atau bersifat istimewa yang diatur dengan undang-undang; (b) Negara mengakui dan menghormati kesatuankesatuan masyarakat hukum adat beserta hak-hak tradisionalnya sepanjang masih hidup dan sesuai dengan perkembangan masyarakat dan prinsip Negara Kesatuan Republik Indonesia, yang diatur dalam undang-undang.
} 
Proses Penanganan Perkara di Kepolisian Kutai Timur terhadap Pelanggaran Hukum Pidana Adat di Desa Nehas Liah Bing

Proses penangan perkara di Kepolisian Kutai Timur terhadap pelanggaran hukum pidana adat pada Desa Nehas Liah Bing ini menimbulkan persoalan hukum, terkait kepastian hukum terhadap sanksi adat yang telah diberikan oleh peradilan adat yang memiliki kekuatan memaksa. Di sisi lain pihak Kepolisan Kutai Timur, terhadap laporan pelanggaran hukum atas penganiayaan ringan telah memproses secara hukum berdasarkan LP/59/III/2015/Kaltim/Res Kutai Timur/Sektor Muara Wahao tanggal 7 Maret 2015. Penerapan tindak pidana ringan berupa penganiayaan ringan merupakan delik murni dan bukan delik aduan, sehingga terhadap delik ini tidak dapat dicabut oleh kedua belah pihak yang berperkara. Perkara penganiayaan ringan yang terjadi pada Desa Nehes Liah Bing merupakan delik murni karena pelaku dan korban tidak memiliki ikatan kekeluargaan.

Kepolisian berdasarkan dengan Pasal 18 Undang-Undang Kepolisian No 2 Tahun 2002 tentang Kepolisian memiliki kewenangan diskresi untuk melanjutkan atau menghentikan perkara. Upaya yang dilakukan pihak Kepolisian Resor Kutai Timur melalui restorative justice berupa tindakan mediasi penal guna mendapatkan keadilan, kemanfaatan dan kepastian hukum. Penyidik Kepolisian Resor Kutai Timur dalam penerapan sistem peradilan pidana dapat menggunakan diskresi dalam menyelesaikan suatu perkara pidana bahkan pelaksanaan nilai-nilai keadilan restoratif oleh aparat kepolisian telah diberikan suatu dasar hukum berupa Surat Keputusan Kapolri No Pol : B/3022/XII/2009/SDEOPS, tanggal 14 Desember Tahun 2009 tentang penanganan kasus melalui Alternatif Dispute Resolusion (ADR). ${ }^{8}$ Sehubungan dengan rujukan tersebut di atas, dijelaskan kembali bahwa salah satu bentuk penyelesaian masalah dalam penerapan restorative justice adalah menerapkan mediasi penal yakni pola penyelesaian masalah sosial melalui jalur alternatif selain proses hukum non litigasi antara lain melalui upaya perdamaian, dengan tujuan mengupayakan penanganan kasus pidana yang mempunyai kerugian materi kecil, penyelesaiannya dapat diarahkan

\footnotetext{
${ }^{8}$ Saat ini dapat merujuk pada aturan terbaru Surat Edaran Kapolri Nomor : SE/8/VII/2018 tentang Penerapan Keadilan Restoratif (Restorative Justice)
} 
melalui konsep ADR; Penyelesaian kasus pidana dengan menggunakan ADR harus disepakati oleh pihak-pihak yang berperkara namun apabila tidak terdapat kesepakatan baru diselesaikan sesuai dengan prosedur hukum yang berlaku secara profesional dan proporsional; dan Penyelesaian kasus pidana yang menggunakan ADR harus berprinsip pada musyawarah mufakat dan harus diketahui oleh masyarakat sekitar dengan menyertakan RT RW setempat; dan Penyelesaian kasus pidana dengan menggunakan ADR harus menghormati norma hukum sosial / adat serta memenuhi asas keadilan; dan untuk kasus yang telah dapat diselesaikan melalui konsep ADR agar tidak lagi di sentuh oleh tindakan hukum lain yang kontra produktif.

Konsep restorative justice mengakomodasi kepentingan korban dan pelaku tindak pidana, serta mencari solusi yang lebih baik untuk kedua belah pihak. Tindakan restorative justice melalui mediasi penal dipilih oleh pihak penyidik karena dengan melakukan proses mediasi tidak hanya dicari sebuah kepastian hukum namun proses menyelesaikan masalah secara cepat, mudah dan ringan. Restoratif justice merupakan salah satu instrumen dari konsep keadilan restoratif. Keterlibatan aparat penegak hukum hanyalah sebagai mediator, yang menyelesaikan perkara tanpa diajukan ke tingkat pengadilan. Pertimbangan-pertimbangan polisi untuk menyelesaikan perkara tanpa diajukan ke pengadilan adalah ${ }^{9}$ bahwa yang diinginkan masyarakat sebenarnya lebih di titik beratkan bukan pada pengakan hukumnya, akan tetapi kepada nilai-nilai ketentraman dan kedamaian masyarakat, penyelesaian melalui hukum/pengadilan tidak akan memecahkan masalah, seringkali hanya memperluas pertentangan dan rasa tidak senang antar warga masyarakat yang berperkara, dan perkara yang diadukan kadang-kadang tidak mempunyai dasar hukum untuk diselesasiakan secara hukum.

Mediasi muncul sebagai salah satu pemikiran alternatif dalam pemecahan masalah sistem peradilan pidana. Hal ini berawal dari wacana restoratif justice yang berupaya untuk mengakomodir kepentingan korban dan pelaku tindak pidana, serta mencari

\footnotetext{
${ }^{9}$ E.K.M. Masinambow, 2013, Hukum dan Kemajemukan Budaya, Yayasan Obor Indonesia, Jakarta, hlm 153.
} 
solusi yang bersifat "menang-menang" (win win solution), bukan menang kalah dan mengatasi berbagai persoalan sistem peradilan pidana yang lain.

\section{Penerapan Restoratif Justice terhadap Pelaku Tindak Pidana Ringan yang Telah diberikan Sanksi Adat di Satuan Reserse Kriminal Kepolisian Resor Kutai Timur}

Pancasila dan Undang-undang Dasar 1945 merupakan dasar hukum Negara Republik Indonesia, namun demikian Negara Republik Indonesia mengakui dan menghormati kemajemukan hukum diantaranya adalah hukum negara, hukum agama dan hukum adat. Kemajemukan hukum adalah pandangan bahwa dalam dunia pragmatis sedikitsedikitnya terdapat dua sistem norma, dua sistem aturan terwujud di dalam interaksi sosial dan bagaimana hukum itu berperan dan menyesuaikan diri di dalam kondisi seperti itu. Sehubungan dengan pendapat diatas tersebut maka Indonesia merupakan negara dengan keberagaman hukum yang pada masyarakatnya memiliki hak dalam menyelesaikan permasalahan dengan menurut hukum apa yang dianggapnya memberikan rasa keadilan. ${ }^{10}$

Pada hakekatnya keberadaan mengenai hukum adat Desa Nehes Liah Bing beserta hakhak tradisionalnya telah diakui oleh negara republik Indonesia. ${ }^{11}$ Amandemen UndangUndang Dasar 1945 Bab VI tentang Pemerintahan Daerah merupakan dasar hukum terbentuknya hukum adat pada seluruh wilayah Republik Indonesia. Hukum adat pada Desa Nehes Liah Bing berada pada wilayah hukum Polres Kutai Timur, hukum ini

10 Eduard Karel Markus Masinambow, 2003, Hukum dan Kemajemukan Budaya, Edisi ke-2, Yayasan Obor Indonesia, Jakarta, HIm 5-6.

${ }^{11}$ hal tersebut tercantum didalam Pasal 18 huruf b Amandemen Undang-Undang Dasar 1945 Bab VI tentang Pemerintahan Daerah, yaitu, (1) Negara mengakui dan menghormati satuan-satuan pemerintahan daerah yang bersifat khusus atau bersifat istimewa yang diatur dengan undang-undang; (2) Negara mengakui dan menghormati kesatuan-kesatuan masyarakat hukum adat beserta hak-hak tradisionalnya sepanjang masih hidup dan sesuai dengan perkembangan masyarakat dan prinsip Negara Kesatuan Republik Indonesia, yang diatur dalam undang-undang. 
merupakan suatu norma-norma atau aturan asli Suku Dayak Wehea yang dibuat, disepakati dan dilaksanakan oleh warga Desa Nehes Liah Bing serta memiliki sanksi yang tegas dan mengikat bagi warga Desa Nehes Liah Bing tersebut sehingga dengan adanya hal tersebut diatas, maka hukum tersebut memiliki kekuatan sebagai sifat pemaksa.

Terkait dengan hal tersebut menurut Masinambow dalam bukunya yang berjudul hukum dan kemajemukan budaya, mengemukakan bahwa masyarakat memiliki aturan-aturan tersendiri yang terbentuk di dalam masyarakat tersebut sehingga memiliki kekuatan yang memaksa di dalam kelompok-kelompok sosial, dimana hal ini merupakan suatu bentuk penjabaran dari nilai-nilai estetika yang luhur, dan apabila terjadi penyimpangan yang dilakukan oleh individu dari kelompok masyarakat maka akan mendapat sanksi yang bersifat pemaksaan. ${ }^{12}$ Hal tersebut sesuai dengan Desa Nehes Liah Bing yang memiliki sistem hukum adat tersendiri berikut dengan sanksi tegas serta memiliki kekuatan memaksa apabila dilanggar oleh seseorang.

Sanksi tegas dan kekuatan memaksa ini dijelaskan di dalam definisi hukum, yaitu bahwa hukum memiliki prinsip-prinsip dan ciri yang tetap yaitu : Pertama, Hukum merupakan suatu organ peraturan-peraturan yang abstrak dan kedua, bahwa hukum merupakan suatu proses sosial untuk mengadakan tertib hukum dan mengatur kepentingan-kepentingan manusia. ${ }^{13}$ Sehubungan dengan hal tersebut bahwa hukum adat pada Desa Nehes Liah Bing telah memiliki lembaga adat atau kapakat isen mulang wehea yang berfungsi sebagai organ peraturan-peraturan yang abstrak dan sebagai proses sosial dalam kepentingan-kepentingan manusia. Hukum adat Suku Dayak Wehea yang berada pada Desa Nehes Liah Bing merupakan hukum tidak di kodifikasikan. Istilah hukum adat yang tidak dikodifikasi dikatakan oleh Soekanto dalam bukunya meninjau hukum adat indonesia yang dikutip Bushar Muhammad bahwa hukum adat merupakan suatu hukum yang kompleks dan tidak dilakukan kodifikasi atau dikitabkan namun walaupun tidak dikodifikasi, dan memiliki sifat yang

12 Eduard Karel Markus Masinambow, 2003, Hukum dan Kemajemukan Budaya, Edisi ke-2, Yayasan Obor Indonesia, Jakarta, HIm 68.

${ }^{13}$ Bambang Waluyo, 1991, Penelitian Hukum Dalam Praktek, Sinar Grafika, Jakarta, HIm 17. 
memaksa (dwang) serta sanksi hukum (rechtsgevolg). ${ }^{14}$ Atas kekuatan yang memaksa dan memiliki sanksi hukum tersebut maka hukum adat Desa Nehes Liah Bing merupakan hukum yang tidak dikodifikasi dan penyelesaian permasalahan tanpa diselesaikan melalui hukum negara yang ada yaitu melalui sistem peradilan pidana.

Penerapan restoratif justice terhadap pelaku tindak pidana ringan yang dilaporkan kepada Kepolisian Resor Kutai Timur,dalam hal ini supaya tidak ada penerapan sanksi hukum ganda terhadap perkara tersebut. Penyidik Satuan Reserse Kriminal Kepolisian Resor Kutai Timur berdasarkan Pasal 18 Undang-Undang No. 2 Tahun 2002 tentang Kepolisian Negara Republik Indonesia mengenai diskresi kepolisian dan Surat Kapolri No Pol : B/3022/XII/2009/SDEOPS, tanggal 14 Desember Tahun 2009 tentang penanganan kasus melalui Alternatif Dispute Resolusion (ADR) ini, menerapkan restorative justice melalui mediasi penal agar perkara tersebut mendapatkan kepastian, keadilan dan kemanfaatan hukum. Pemberlakuan restorative justice oleh pihak penyidik Satuan Reserse Kriminal Kepolisian Resor Kutai Timur dalam tindak pidana penganiayaan ringan yang dilakukan pelaku telah diperlakukan restorative justice berdasar pertimbangan sebagai berikut:

(1). Bahwa yang diinginkan masyarakat sebenarnya lebih di titik beratkan bukan pada pengakan hukumnya, akan tetapi kepada nilai-nilai ketentraman dan kedamaian masyarakat; dan

(2). Penyelesaian melalui hukum/pengadilan tidak akan memecahkan masalah, seringkali hanya memperluas pertentangan dan rasa tidak senang antar warga masyarakat yang berperkara; dan

(3). Perkara yang diadukan kadang-kadang tidak mempunyai dasar hukum untuk diselesasiakan secara hukum.

Berdasarkan pertimbangan tersebut, apabila pihak penyidik tetap memproses perkara hingga kepada tahap penuntutan akan terjadi penerapan hukum yang ganda, yakni hukum negara dan hukum adat sehingga akan berdampak munculnya ketidakadilan hukum. Faktor-faktor yang mempengaruhi dalam pemberlakuan restorative justice oleh

\footnotetext{
${ }^{14}$ Bushar Muhammad, 2003, Asas-Asas Hukum Adat suatu Pengantar, Cetakan 12, PT Pradnya Paramita, Jakarta, HIm 11.
} 
pihak penyidik Satuan Reserse Kriminal Polres Kutai Timur terhadap pelaku tindak pidana ringan yang telah diberi sanksi adat oleh lembaga adat diantaranya adalah Personil Satuan Reserse Kriminal Kepolisian Resor Kutai Timur yang terbatas; Koordinasi antara lembaga adat Desa Nehes Liah Bing dengan kepolisian Resor Kutai Timur; Berdasarkan Pasal 18 Undang-Undang Kepolisian No 2 Tahun 2002 mengenai Kepolisian Negara Republik Indonesia dan Surat Kapolri No Pol : B/3022/XII/2009/SDEOPS, tanggal 14 Desember Tahun 2009 tentang penanganan kasus melalui Alternatif Dispute Resolusion (ADR).

Penerapan restoratif justice terhadap pelaku tindak pidana ringan yang telah diberikan sanksi adat di Satuan Reserse Kriminal Kepolisian Resor Kutai Timur mendasarkan pertimbangan-pertimbangan yang disebutkan diatas. Selain itu proses penyelesaian sengketa berdasarkan hukum adat terhadap pelanggaran hukum adat, dengan diberikan sanksi adat oleh lembaga adat, secara hukum dibenarkan sebagai bentuk perwujudatan keberadaan dan pengakuan hukum adat yang masih ada dan tumbuh dalam masyarakat di Indonesai.

\section{SIMPULAN}

Kepolisian menyelesaikan perkara dengan menggunakan konsep restorative justice yang diatur Pasal 18 Undang-Undang Republik Indonesia Nomor 2 Tahun 2002 tentang Kepolisian Negara Republik Indonesia dan Surat Keputusan Kapolri tahun 2009, Nomor Polri : B/3022/XII/2009/SDEOPS tentang penanganan kasus melalui Alternatif Dispute Resolution (ADR) Tanggal 14 Desember 2009 dengan pertimbangan faktor kuantitas dan kualitas personil polri, faktor koordinasi antara lembaga adat dengan pihak penyidik kepolisian, dan faktor peraturan perundang-undangan yang dijadikan pedoman oleh pihak penyidik Kepolisian Resor Kutai Timur dalam melaksanakan restorative justice melalui diskresi kepolisian. 


\section{DAFTAR PUSTAKA}

Abdul Halim Barkatullah dkk. 2005, Politik Hukum Pidana (Kajian Kebijakan Kriminalisasi dan Dekriminalisasi), Pustaka Pelajar, Jakarta.

Adami Chazawi. 2002, Pelajaran Hukum Pidana Bagian I, PT Raja Grafindo Persada, Jakarta.

Abdussalam. 1997, Pelaksanaan sistem peradilan pidana di Indonesia, Dinas Hukum Polri, Jakarta.

Andi Hamzah. 1994, Asas-Asas Hukum Pidana, Edisi Revisi, Cetakan 2, Rineke Cipta, Jakarta.

Andrew Von Hirsch et all. 2003, Restoratif Justice and Criminal Justice : Competing or Reconcialiable Paradigms, Hart Publishing, Oregon.

Bagir Manan. 2006, Restoratif Justice (Suatu Perkenalan), Majalah Hukum Varia Pengadilan No 247 Juni 2006, PT IKAHI, Jakarta.

Bambang Prasetyo dkk. 2005, Metode Penelitian Kuantitatif Teori dan Aplikasi, Rajagrafindo Persada, Jakarta.

Bambang Waluyo. 1991, Penelitian Hukum Dalam Praktek. PT Sinar Grafika, Jakarta.

Bambang Waluyo. 2000, Pidana Dan Pemidanaan, Sinar Grafika, Jakarta.

Barda Nawai Arief. 1998, Beberapa Aspek Kebijakan Penegakan dan Pengembangan Hukum Pidana. Citra Aditya Bakti, Bandung.

Harun Alrasyid. 2004, Naskah UUD 1945 Sesudah Empat Kali Diubah oleh MPR, Edisi Revisi, Universitas Indonesia Cetakan 1, Jakarta.

Http://www.Tugas Pokok dan Fungsi Kepolisian Negara Republik Indonesia.com/publishers/mod.php, Tugas pokok dan Fungsi Kejaksaan Republik Indonesia, diakses pada tanggal 10 Januari 2016.

Http://www.Lap dal masterplain Kabupaten Kutai Timur/publishers/mod.php, Lap dal masterplain Kabupaten Kutai Timur diakses pada tanggal 19 April 2016.

I Nyoman Sukena. 2008, Peranan Pecalang Desa Adat dalam memelihara keamanan dan ketertiban di Wilayah Tabanan Bali, tesis, program studi fakultas hukum universitas bhayangkara, Jakarta.

Ilham Basri. 2004, Sistem Hukum Indonesia : Prisnsip-Prinsip dan Implementasi Hukum di Indonesia, PT Rajawali Press, Jakarta.

Sulistyowati Irianto. 2007, Antropologi Hukum : Modul A2203/2SKS, Perguruan Tinggi 
Leden Marpaung. 2009, Asas-Teori-Praktek Hukum Pidana, PT Sinar Grafika, Jakarta.

Moeljatno. 2008, Asas-Asas Hukum Pidana, Rineke Cipta, Jakarta.

Muladi dkk. 1992, Bunga Rampai Hukum Pidana, Alumni, Bandung.

Muladi dkk. 2005, Teori-teori dan Kebijakan Pidana, Alumni Cetakan 3, Bandung.

Romli Atmasasmita. 2001, Reformasi Hukum, Hak Asasi Manusia dan Penegakkan hukum, Bandar Maju, Bandung.

Satjipto Rahardjo, 2011, Hukum dan Keadilan Masyarakat Perspektif Kajian Sosiologi Hukum, Setara Press, Malang.

Sadjijono, 2005. Mengenal Hukum Kepolisian Perspektif Kedudukan dan Hubungannya dalam Hukum Administrasi, PT Leksbang Mediatama, Surabaya.

Soerjono Soekanto. 2011, Hukum Adat Indonesia, Rajawali Press, Jakarta.

Zaenal Abidin Farid. 2007, Hukum Pidana 1, Sinar Grafika, Jakarta. 